B 119 高速度カメラによる小形モータの整流火花の撮影

\author{
花澤民雄 $^{\circ}$ (九州産業大学), 大坪広明 (九州産業大学), 江頭虎夫 (九州産業大学)
}

\title{
Photographing the Commutation Spark from Small Motors by High-speed Camera
}

\author{
Tamio HANAZAWA, Hiroaki OTSUBO and Torao EGASHIRA
}

\begin{abstract}
We have done some attempts to understand the mechanism of commutation spark generation in universal motor from the image aspect using a high-speed camera. We have also mentioned about the generation of single and plural number of sparks at one commutator segment and the voltage between brush and commutator segment. The commutation sparks of the motor are generated with a sliding contact between brush and commutator segment in the moment that the segment is separated from the brush. And the width of the brush is just $10 \mathrm{~mm}$, this time, we were able to clarify position of the brush which sparks are generated and the relation between positive brush and negative brush.
\end{abstract}

Keywords: High-speed camera, Commutation spark, Universal motor

\section{1. 緒言}

家電品の掃除機や電動工具等には単相交流整流子電動 機（以後，コニバーサルモータと称す）が用いられるが， このモータは高速回転中にブラシと整流子の間で整流作 用が行われるため, 両者が離れる瞬間に整流火花を発生し， この火花発生がブラシ摩耗や電磁妨害波の原因として問 題となっている. 整流火花は直流機で数多くの研究がなさ れ ${ }^{1) \sim 6)}$ ，そのほとんどが電気的解明で，画像面から解明 された報告はほとんどない。

そこで, 画像面より整流火花の発生メカニズムを解明す るため, 高速度カメラを用いてュニバーサルモータが高速 回転中に発生する整流火花を捉え，画像化をする撮影実験 を行った，そして，整流情報が現れるブラシ整流子片間電 圧（ブラシと整流子片の間の電圧）を計測することで，画 像・電気の両面から解明の試みを行ってきた。

これまで高速度カメラによる撮影実験を行った結果, 整 流火花発生時は整流子片の 1 つ置きに, 電機子端子電圧に 現れる大小繰り返しパルスの大きいパルスと一致する。ま た，火花は 1 整流子片に単数個，複数個発生し，そして， ブラシ整流子片間電圧 (瞬時電圧) 等の関係について報告 をした7８)

今回，コニバーサルモータを交流・直流電源で駆動して 整流火花の撮影実験を行い, 交流・直流駆動時におけるブ ラシ位置の火花発生分布について求め比較検討を行った。 また，直流電源駆動時には電流の流れる方向，すなわち，
正ブラシ（ブラシから整流子へ電流が流れる方向）と負ブ ラシ（整流子からブラシへ電流が流れる方向）の電源極性 を考慮して，正ブラシと負ブラシでそれぞれ撮影実験を行 った，その結果，負ブラシにおいては正ブラシの撮影時に 比べ数\%しか撮影をすることが出来ない現象が見られた。 そこで, 正ブラシと負ブラシにおける整流火花の発生現象 について検討を行ったので報告する．

\section{2．高速度カメラによる撮影実験}

ユニバーサルモータが高速回転中にブラシと整流子片 間で発生する整流火花を撮影するため，撮影速度が毎秒 2,000〜20,000,000 コマの撮影が可能な高速度力メラを用 いた ${ }^{9\}}$. カメラのシャッタリング (トリガ信号) にレーザ 光を利用した外部トリガ法を用い，また，電気的情報を得 るために, ブラシ整流子片間電圧とカメラのトリガ信号を 同時にオシロスコープで計测できるように設定し，交流・ 直流電源でモータを回転させて撮影実験を行った。

高速度カメラを用いてユニバーサルモータが高速回転 中に発生する整流火花を捉え,ブラシのどの位置より発生 しや寸いのか検討するために，モータ 1 回転に要する時間 と高速度力メラの撮影速度を知る必要がある。

実験機は整流子片が 28 個設けられているが，火花は整 流子片の 1 つ置きに発生することから，1回転中の全ての 


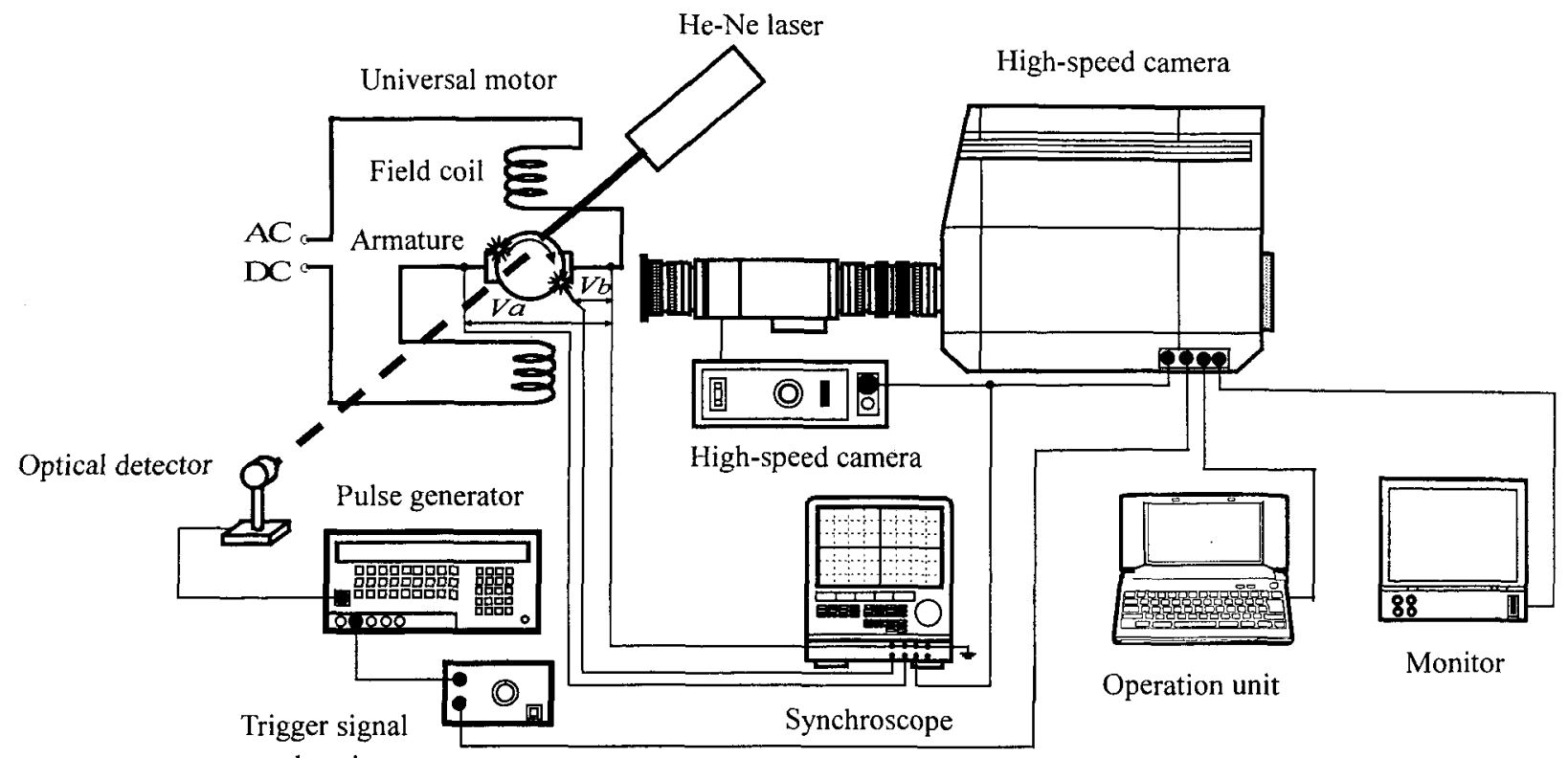

Fig.1 Experimental setup for photographing

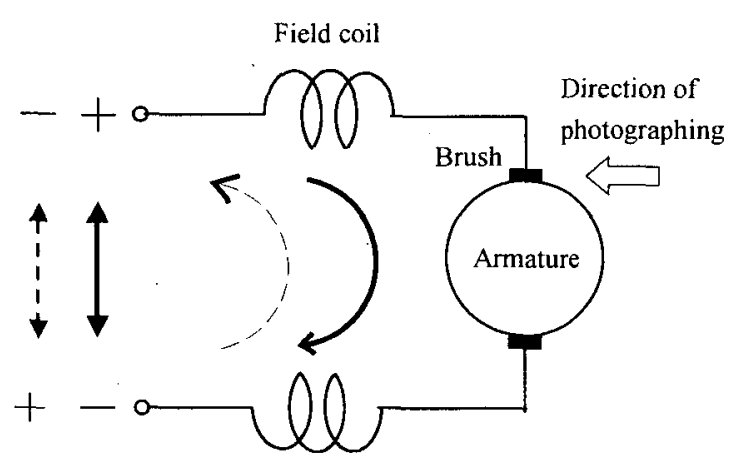

Field coil

solid line : Current direction of positive brush dotted line : Current direction of negative brush

Fig.2 Current direction of positive brush and negative brush

火花を撮影するには整流子片の 14 箇所が記録できればよ い事になる．そこで，モータの回転速度が 18,500 rpm の とき整流周期 $232 \mu \mathrm{s}$ が得られ，撮影速度を 4,300 コマ/s に決 めると 1 コマのインターフレームは約 $232 \mu \mathrm{s}$ になる. また， 露出時閒については $50 \mu \mathrm{s}$ に全て設定したが，これは回転 速度に多少のバラッキがあるので，パルス間とインターフ レームの関係を補うためである。このような撮影条件で交 流・直流電源でそれぞれ 50 回の撮影を行って，火花が捉 えられた発生位置と発生回数の火花発生分布を求めた。

また, 直流電源によりモータを回転すると二䇢所設けら れたブラシと整流子の間を流れる電流の方向が違うこと から，ブラシから整流子几流れる場合を正ブラシ，整流子 からブラシへ流れる場合を負ブラシと呼ばれている.モー
タの整流火花を撮影する位置は 1 籄所に設定しているた め, 直流電源による実験では GND を同じ位置に取ること で, 電源の極性を切り替え正ブラシ, 負ブラシについても 同様に 50 回づつの撮影実験を行った．Fig.1にその撮影 実験装置構成図を示し，Fig.2 に正ブラシと負ブラ シの電流方向を示す。

\section{3. 実験結果と考察}

\section{1 火花発生分布}

実験機の整流子片は 28 個設けられ，使用されているブ ラシサイズは $10.0 \times 6.2 \times 28.4 \mathrm{~mm}$ のカーボンブラシであり 整流火花は整流子片の1つ置きに発生するため, モータが 1 回転する間に整流子片の 14 箇所で発生する。 そこで, モ一夕を回転速度 $18,500 \mathrm{rpm}$ 一定に保ち, 整流子片の 14 䇢所を撮影枚数 15 コマに記録するには，1 コマづつ 1 整流子 片を撮影するようにした，そして，上述のような撮影撮影 速度と撮影条件で交直電源運転時においてそれぞれ 50 回 の撮影を行い, 火花が捉えられたブラシ位置におらける発生 回数について画像解析を行って,火花発生分布を求め比較 検討を行った.

交・直流運転において 50 回づつの撮影を行った結果, 撮影コマ数は 700 コマ（15コマ目は1コマ目と重なるので削除し た）で，交流時には，火花発生が捉えられていたコ又数は 160 コマで，直流運転には 109 コマが撮影された。

Fig. 3に交流時の撮影結果の一例を示すが,この撮影結 果から火花は 2,5,8,9,13 コマ目 (○印) の 5 籄所から発生し ているのが捉えられている．また，Fig. 4 に直流運転時の 撮影結果の一例を示すが，この撮影結果では，火花は 1,6,12 コマ目（○印）の 3 箇所より発生しているのが捉え 


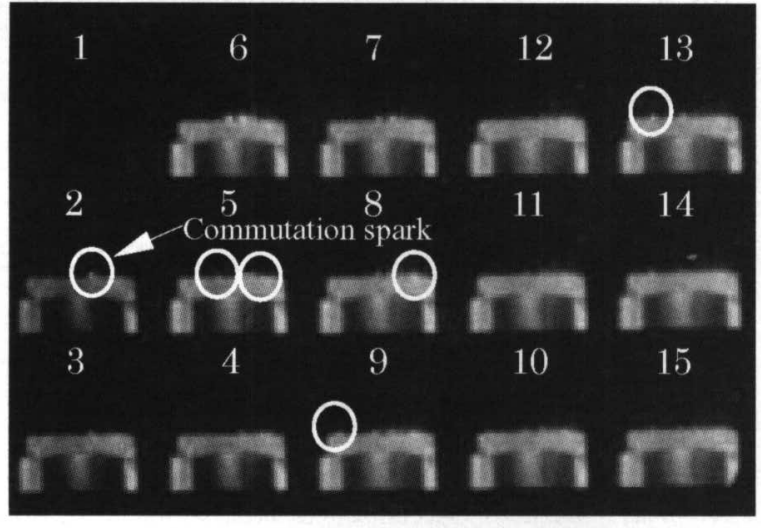

Fig.3 Commutation spark (4,300 frame/s)

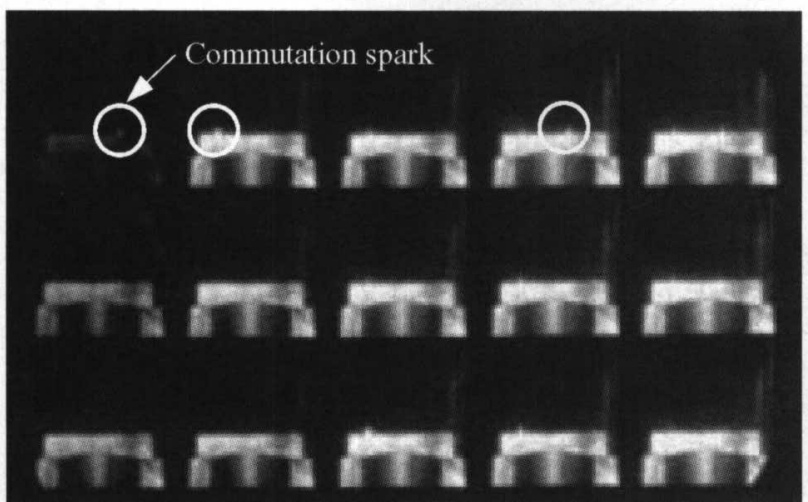

Fig.4 Commutation spark (4,300 frame/s)

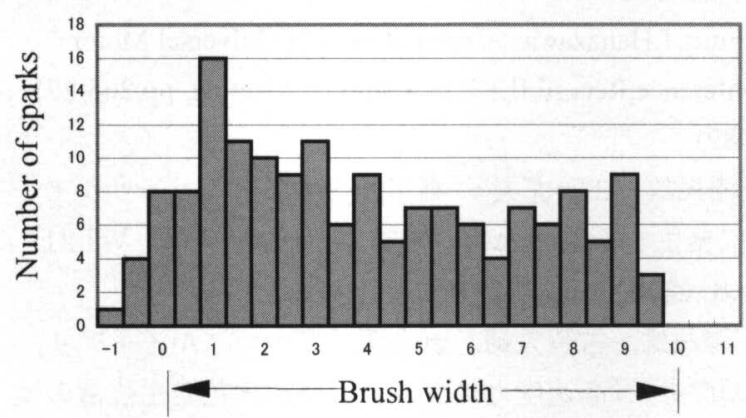

Spark position $[\mathrm{mm}]$

Fig.5 Position and number of spark generation (AC)

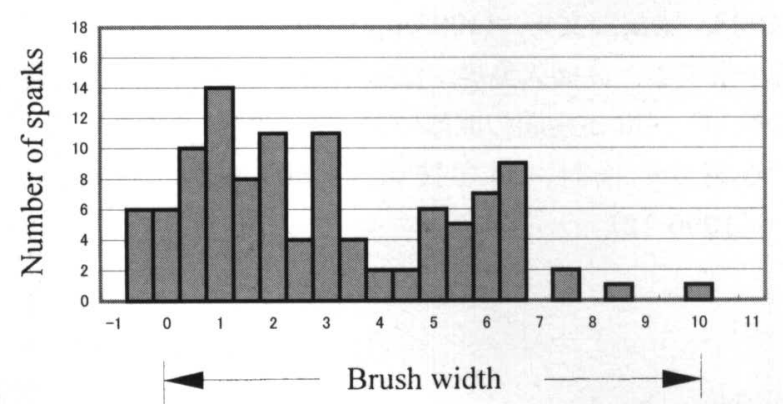

Spark position $[\mathrm{mm}]$

Fig.6 Position and number of spark generation (DC)
られている.これらの撮影結果から画像解析を行い, モ一 タのブラシ幅が $10 \mathrm{~mm}$ であるので, 20 等分して $0.5 \mathrm{~mm}$ づつの範囲でブラシの火花発生位置と発生回数を求め, そ の結果を Fig. 5, Fig. 6 に示した. 整流火花は交流運転 時にはブラシ幅の全体で火花発生が見られるが, 直流運転 時ではブラシ幅の左側の方に多く発生しているのが顕著 に捉えられている。

これは左側の方に電機子コイルが接続されているため, 電流は電機子コイルの方に向かって流れるが, 直流運転時 は交流運転時に比べ, 特にその傾向が強く出るのではない かと思われる.

\section{2 正ブラシ, 負ブラシにおける整流火花}

直流駆動時においてユニバーサルモータに発生する整 流火花が, 正ブラシと負ブラシでどのように発生するか撮 影実験を行った. 撮影条件は同様にモータ 1 回転中に発生 する火花を全て記録するために撮影速度 $4,300 \mathrm{I} / \mathrm{s}$ に設 定し, 整流子片の 14 箇所を記録枚数 15 コマに 1 コマづつ記 録して, それぞれ 50 回の撮影を行い, 発生した整流火花 の画像解析を行った. 各 50 回の撮影結果より, 撮影コ又数 は 700 コマ（15 コマ目は 1 コマ目と重なるので削除した）で,

Table 1 に火花が撮影されたコ又数を示すが, 正ブラシでは 火花発生が捉えられた对数は 194 双, 負ブラシでは 2 コ又 であった. Fig. 7 に正ブラシにおける撮影結果の一例を示 すが，この撮影された写真では， $2,4,5,6,7$ 卭目 (O 印）の 5 籄所から発生した整流火花が捉えられている.

このようにして求めた 50 回の撮影結果より画像解析を 行い, 正ブラシ, 負ブラシの火花発生位置を求めた. Fig. 8 にブラシ幅に対する火花発生位置を示すが, 正ブラシで

Table.1 Commutation spark by positive brush and negative brush

\begin{tabular}{|c|c|c|}
\hline & Positive brush & Negative brush \\
\hline Number of sparks & 194 & 2 \\
\hline
\end{tabular}

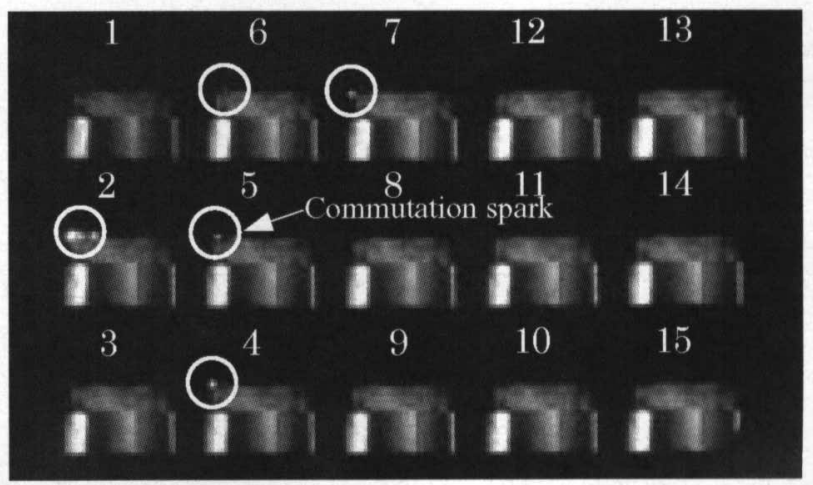

Fig.7 Commutation spark (4,300 frame/s) 


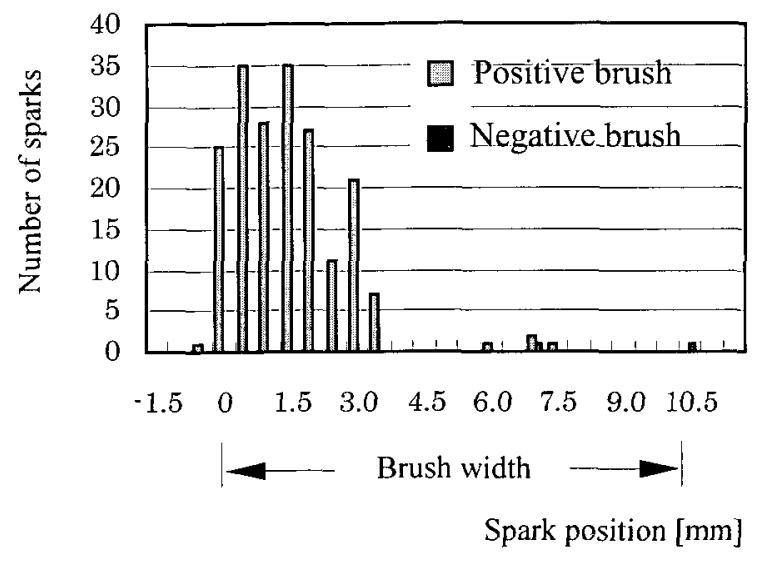

Fig.8 Position and number of spark generation

は火花がブラシ幅 $0 \sim 3.5 \mathrm{~mm}$ の左側の方に集中して現れ ている.また，負ブラシにおいて捉えられた 2 水の火花は 右側で発生していた。ここで, 火花が負ブラシにおいて何 故正ブラシと比較して数\%しか撮影出来なかった理由に ついて検討した。

正ブラシ,負ブラシにおいて高速度カメラにより撮影を 行うと上述の結果が得られた。 そして, 目視による観察で は両者ともに整流火花の発生が見られる，そこで,ビデオ カメラにより撮影を行うと, 明らかに違いが現れ, 正ブラ シでは火花がブラシの縁で放電しているのが捉えられる。 負ブラシではブラシと整流子面の中で放電するために捉 えにくいことが明らかになった。

この原因について, ブラシは炭素 (C), 整流子は銅 $(\mathrm{Cu})$ の材質により形成され，正ブラシでは整流子が陰極，負ブ ラシではブラシが陰極になり，再者の融点や沸点が大きく

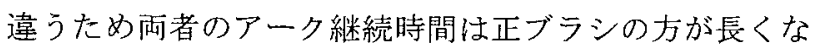
る10). したがって，陰極が銅（Cu）である正ブラシは炭 素（C）より金属蒸気を発生し易く，アークを維持し易い ため火花がブラシの縁まで引っ張られて放電するものと 推察される．また，負ブラシではアークを維持する時間が 短いため,ブラシの縁まで維持して放電することが出来ず， ブラシと整流子の中で放電現象を起こ卞ものと考えられ る。

\section{4. 結言}

交流・直流電源駆動によるコニバーサルモータの整流火 花を捉えるため, 高速度力メラを用いてモータ 1 回転中に 発生する全ての火花撮影を行い, 火花がブラシ幅のどの位 置で発生するか火花発生分布を求めた. また, 直流運転時 の正ブラシ,負ブラシにおける撮影では負ブラシにおいて 整流火花が撮影できない現象が見られたので，その原因に ついて比較検討を行い，以下のような結果が得られた。

（1）整流火花はブラシ位置の左側で集中して発生し易 い.
（2）整流火花の発生は直流電源駆動時の方がブラシ左 側で発生し易いことが顕著である。

（3）整流火花はアーク継続時間の違いにより，正ブラシ ではブラシの縁で，負ブラシではブラシの中で発生 する。

今後は, 整流火花の単数個, 複数個発生が起こる原因等 について検討したい。

\section{参考文献}

1 )林邦雄, 内藤正木: 「直流機整流曲線の解析」, 電学雑, Vol.79, No.852(1959) pp.1137-1145

2)松田敏彦，鈴木好夫：「直流機の無火花帯とブラシ接触 電圧特性との関係」, 電学論 B, Vol.101, No.10 (1981) pp.603-610

3)仲村節男, 森田登, 都甲哲:「ピーク負荷繰返し時にお ける直流機の整流について」, 電学論 D, Vol.108, No.11

(1988) pp.1025-1032

4 )小原木春雄, 田原和雄, 石井吉太郎, 鈴木俊:「小形交 流整流子電動機における異数巻電機子巻線方式の適用 之整流性能評価」, 電学論 D, Vol.115, No.4（1995） pp. $488 \cdot 494$

5 )中田高義, 高橋則雄, 泰田直行, 児玉保久, 藤原俊明 : 「整流特性が考慮可能な有限要素法による単相直巻整 流子電動機の解析」, 電学論 B, Vol.104, No.12（1981） pp. 809-816

6 )T.Fujii,T.Hanazawa: "Commutation of Universal Motors", Conference,Record,IEEE,ISA,Annual Meeting, pp.265-271 (1989)

7 )花澤民雄, 江頭虎夫 :「高束回転中のコニバーサルモー 夕に発生する整流火花の撮影」, 可視化情報, Vol.21, No.8 (2001) pp.115-121

8 ) 花澤民雄, 古賀大輔, 恵良董, アルマズルイ・アリ, 江頭虎夫：「高速度力メラによる整流火花発生位置の検 討」, 可視化情報学会全国講演会講演論文集, Vol.23, No.2（宇都宫 2003）pp.75-78

9 )安藤幸司:「新世代イメージコンバータカメラの開発」, 高速度撮影とフォトニクスに関する総合シンポジウム 1993，講演論文集，(1993)pp.93-96

10)小泉俊彰, 高橋久美雄, 江原康生, 兽根秀昭, 根元義 章 : $\mathrm{C}-\mathrm{Cu}$ 電極閒の開離時アークと電磁ノイズに関す る実験的検討，信学技報，EMD96-87, pp.73-77 (1996-12) 